Journal

of Geography,

Politics and Society

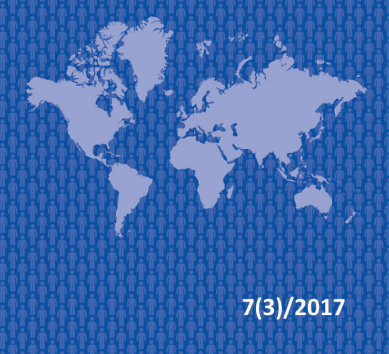

\section{Journal of Geography, Politics and Society}

$2017,7(3), 31-35$

DOI 10.4467/24512249JG.17.024.7180

\title{
QUALITY OF EDUCATION AND ECONOMIC SECURITY OF HIGHER EDUCATION INSTITUTIONS: DIALECTICAL UNITY AND MANAGEMENT SPECIFICS IN UKRAINE
}

\author{
Volodymyr Kovrehin \\ Department of Finance, National University of Civil Protection of Ukraine, Lermontovska 28, 61023 Kharkiv, Ukraine, \\ e-mail: dergupr@nuczu.edu.ua
}

\section{Citation}

Kovrehin V., 2017, Quality of education and economic security of higher education institutions: dialectical unity and management specifics in Ukraine, Journal of Geography, Politics and Society, 7(3), 31-38.

\section{Abstract}

The relation and dialectical unity of such categories as quality of education and economic security of higher education institutions are scientifically proven in the paper. Among such institutions the following two groups are distinguished: state (i.e., all-Ukrainian) and regional. The operation state of the latter is investigated on an example of the Kharkiv oblast. The main components of the management cycle of education sector in Ukraine and such elements of quality of education as quality of the educational process, quality of students training, quality of educational services and quality (state) of education economics in whole country, region, or a single educational institution are determined. Current study proves that the education quality issues need regular state and public monitoring, as they are caused by the requirements of today's market and by increasing competition for students between higher education institutions.

\section{Key words}

management cycle, higher education institution of Ukraine, quality of education, economic security, human resources, economic and innovative potential of Ukraine.

\section{Introduction}

It has become an axiom for today's market economy that it requires proper maintaining at the appropriate quality level (so-called "standard of living") of all sectors of both the economy and society. Modern economy is known to be "a knowledge economy". This requires continuous improvement in the educational level of society, because otherwise it is impossible to create a competitive economy in a whole country and its regions in particular (Поступна, 2011).

The aforementioned idea does not require active scientific-theoretical or practical discussion and debate to be proved. At the same time, there is a problem of improving in quality of education, with the aim to ensure its competitiveness among the educational systems of other countries and support the state's reputation on the global stage. First of all, this requires us to give exact definition and description of such phenomenon as the "quality of education" 
because formation of market relations in the sphere of education put forward new requirements for the strategic development of higher education institutions as a unified educational, and scientific, and industrial complex. One of the directions of this strategy is to form a fundamentally new set of economic relations in the higher education institutions. It must be the direction of innovation and entrepreneurship economic security (Dombrovska, 2016). Its main point lies in the fact that higher education institution must provide academic activities (training of qualified specialists and scientific research), and support entrepreneurship, focused on the use of its potential with the aim of: (1) the further integration of education, science and industry; (2) staff training in the field of administrative, innovative and regional management; (3) extension of the institution's economic opportunities.

The scientific method of our research is based on theoretical and methodological principles of organization, state management and economics of education (Домбровська, 2010; Бєлова, 2014). However, in today's market conditions the study of main matter and improving of state management in the field of education requires us to use the complex and innovative approaches in order to ensure the economic security of an higher education institution and regional socio-economic systems.

Therefore, the aim of this paper is to define the dialectical unity of quality of education and economic security of the higher education institution, and to regulate the legislative background of its activities organization in this context.

\section{Features of the quality of management education in Ukraine}

The quality of education is not a permanent category, and requires continuous improvement, and changes, i.e., management. Though, before managing the quality, it is necessary to carry out such activities as planning, motivation and control. Moreover, the education quality level and the direction of changes must be determined first. This, in its turn, requires an evaluation of education quality. Consequently, a management cycle in the education field is as follows: Management of education quality $\rightarrow$ Monitoring of educational quality $\rightarrow$ Evaluation of educational quality $\rightarrow$ Change of education quality $\rightarrow$ Improving of education quality by using the appropriate management tools (fig. 1.).

Modern education is a complex system, formalization of which is a multifaceted challenge. However, it is impossible to evaluate education quality

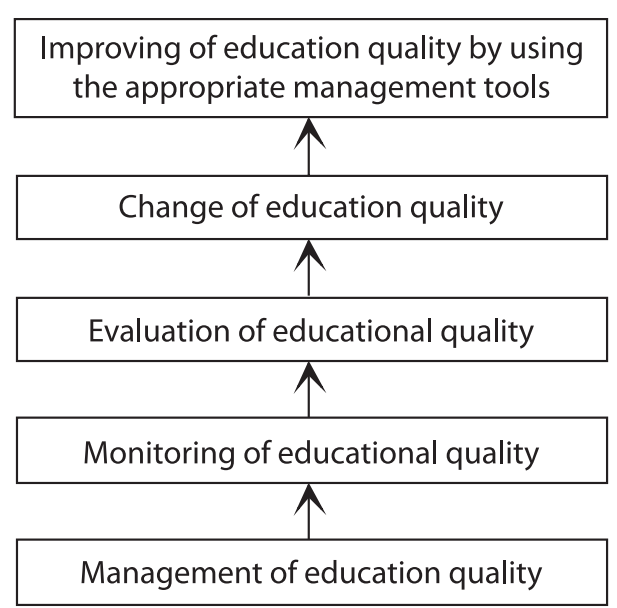

Fig. 1. The management cycle in the education

Source: own study.

without such transformation. That is why problems arise at the stage of educational quality monitoring, which involves evaluating of such condition.

Therefore, there is a problem, which can be resolved only if educational system is divided into subsystems (elements) for their further formalization with transforming quality of education in the categories available for the evaluation, monitoring and management.

We can make an assumption that the different subsystems can be formalized with varying degrees of success. Accordingly, the different efficiency is likely in process of monitoring, control and management of quality of the various elements of the education system.

For the ease of analysis, in terms of interaction and mutual influence of the education quality and economic security, the author of the research underlined four key elements of education quality, based on which education may be considered as an integral system. Consequently, an education quality is as elements: (1) quality of the educational process, (2) quality of students training, (3) quality of the educational services and (4) quality (state) of education economics (fig. 2.).

1. The first element is quality of the educational process. If we talk about education as a development, it is certainly a complex, multi-step process. The base of it lies in the learning process itself. In the management and memetics categories, it can be defined as the process of transfer and perception of a certain number of memes.

According to the objectives of the research we distinguish two forms of the learning process (the current practice and the regulatory framework of education involve a greater number of forms, but the scope of the current work is limited to the following two): 


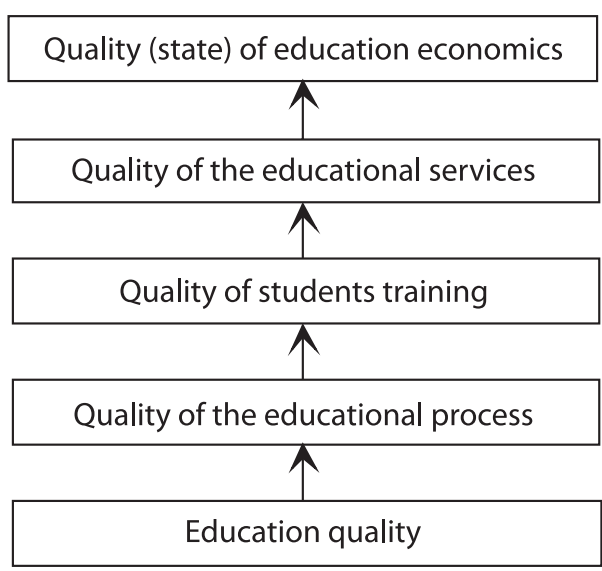

Fig. 2. The key elements of education quality

Source: own study.

1) Direct communication "lecturer-student". In the process of communication, a lecturer using a variety of techniques transfers to students a set of memes, which are enough to form required competences. This way of learning is known to be a full-time in the Ukrainian educational practice.

2) Training with predominance of student's unsupervised work. In this case, the learning process is carried out without the direct guidance of the lecturer, but with their tasks and under their control.

Consequently, students learn most of the memes by themselves, but the lecturer has ability to control the content of a set of these memes and the learning process. One of the type of this form of education is known to be distance learning. In the Ukrainian educational practice, this form of education can be both full-time and part-time, evening, external. These forms vary in the degree of direct involvement of the lecturer in the learning process. All background information about the relation of different forms of learning in modern Ukrainian system of higher education (for the period from 1990 to 2016) can be found on the official website of the State Statistics Service of Ukraine. In addition, the Service offers data on the number of enrolled students in higher educational institutions of I-II and III-IV levels of accreditation, as well as on the number of trained professionals in these institutions for the same period of time (http://www.ukrstat.gov.ua).

It is worth noting that Ukraine has one of the largest number of extramural students in the world. On the one hand it is an indicator of the Ukrainians' desire to get higher education, and on the other hand, we can suppose that quality of education of full-time students is higher than quality of education of extramural students.
As a rule, when speaking today about quality of education, we imply, first of all, quality of the learning (educational) process, including such elements as educational technologies.

2. The second element of the education quality is quality of students training. Speaking about quality of education, the author refers to the standard ISO 9000 , according to which each process has both input and output. Consequently, quality of education also means quality of the input and output products. In this case, quality of learning of a memes set by students is such a product. The content of this set at the output is determined by government in the educational standards (seе: Закон України..., 1991).

Current tool for monitoring of the education level of enrollees, who enter higher education, is external independent evaluation (EIT). The present demographic crisis, which cannot be mentioned, has led to a decrease in the number of students and it, in turn, resulted in relaxed requirements to quality of education of enrollees even in the leading higher education institutions of the country. Thus, some researches outline the engineering and technology education crisis (Сиченко, 2010). Up to $50 \%$ enrollees in the relevant areas are graduates of schools with EIT scores below average in mathematics and physics. It is likely to be very difficult for people with this level of knowledge to develop relevant professional competence.

It is interestingly, there is a group of enrolled students with much higher rates than others in some higher education institutions. Experts have called these higher education institutions "trendy" because low-performing enrollees agree to enter such higher education institution in the less popular field of study (which do not attract them in other higher education institutions), including paid education programs. For example, the Kharkiv National Automobile and Highway University have a very high average and a passing grades for paid training on the road-building faculty (specialty "Ecology and Environment") (Інформація абітурієнту Харківського..., 2016). These characteristics for enrolment on state-financed openings are appropriate to such well-known and top-rated universities as, firstly, the V.N. Karazin Kharkiv National University (the ecological faculty, specialty "Ecology, environmental protection and balanced use of natural resources") and, secondly, the National University of Civil Protection of Ukraine (faculty of technogenic and ecological safety, specialties "Environmental security", "Health and safety") (Інформація щодо..., 2016; Інформація абітурієнту Національного..., 2016). 
Today almost all of the technical, technological, educational and other "specialized" higher education institutions have several educational programs in such fields as economics, management, computer science, humanities and law. The scales of the enrolment for the "non-core" fields are comparable to the "core" fields. Furthermore, the average and passing grades among entrants of the "core" fields, as a rule, are significantly lower (10-15 points) than among those who entered the "non-core"fields. By analyzing the information of Kharkiv region higher education institutions websites, we reach a conclusion that the largest group of high-achieving entrants invests a lot at their future career, which, as it seems to them, is provided by economic-administrative and humanitarian education. Most of these students enter the "top five" best universities of Kharkiv region and one third of these persons chose "core" education.

According to the Ministry of Education and Science of Ukraine, quality of education of entrants, monitored by EIT, proves that higher education institutions, which are evaluated by various ratings as giving the most quality education, usually attract the most prominent students (http://mon.gov.ua, 2016). This certainly gives the higher education institutions an advantage over the others. Taking into consideration that an enrollee is the main resource, which the higher education institution works with and which must be transformed into high-quality specialist, we can affirm that quality of training of recent graduates directly depends on quality of training of the entrants.

In Ukraine, state control of education quality is traditionally common, but today the development of the system of public control, public and professional accreditation of higher education institutions operating in the industrialized countries become actual.

In the $1990^{\text {th }}$ (at the beginning of Ukrainian independence), many parents and employers were poorly competent in quality of education, and educational results in a variety of higher education institutions were not clear, but today the situation has changed. Demand for education and for graduate shifted to the group of higher education institutions, graduates of which demonstrate the ability to get a prestigious job, make a career and earn more than others. The two following groups of such higher education institutions can be identified: all-Ukrainian and regional. At all these higher education institutions, the attention is increasingly focused on both the effective demand and the demand from high-achieving entrants (the winners of Olympiads and those, who have EIT average score above 90 out of 100).
3. The third element of quality of education is quality of the educational services provided to the population and satisfying specific needs of society. We can affirm that the classification of services in Ukraine is based on a sectoral approach and is related to the traditional practice of management and issues of state regulation of the service sector.

Ukraine does not buy educational services for its residents. Our government creates the state higher educational institutions and funds them, i.e., pays their expenses from the funds of the budget. Private educational institutions can get budget funds only if they are accredited and implement the general education program. From an economic point of view, we can say that the educational services are services paid by a private person. Nevertheless, the Ukrainian experience shows that, as a rule, students who have paid for educational services and students who get it at state expense can study in one group. Accordingly, it is necessary to divide the concepts "quality of education" and "quality of educational services". This is due to several factors as requirements of today's market and increasing competition for students between higher education institutions.

4. The fourth element of the education quality is quality (state) of education economics. It must be considered either at the state and regional level or at the level of higher education institutions. In our opinion, the most important indicator of quality of education economics is the level of economic security of the educational institution.

\section{Features of the relation between the education quality and economic security in Ukraine}

Speaking about the current state of the economy of the modern Ukrainian higher education it is necessary to note that the number of non-state higher education institutions has increased during the last 20 years. Due to the recent structural changes in the state management system of Ukraine the number of fee-paying students at the state higher education institutions also has grown. The relation between the education quality and economic security depends on the duration of improvement or deterioration of education quality and economic security indicators. In our opinion, short-term increase or decrease in the level of one aspect does not affect the second aspect, as well as single violations of education quality or economic security does not affect their interdependence and interplay. However, the issues of education quality require permanent state and public control and attention, as well as in-depth scientific 
study. This is due to the requirements of today's market and increasing of competition for students between higher education institutions.

\section{References}

Dombrovska S., 2016, Scientific and methodological basis for the formation and implementation of economic safety management of higher educational establishment, Scientific Light, 2, 19-24.

http://mon.gov.ua, The official website of Ministry of Education and Science of Ukraine [06.11.2016].

http://www.ukrstat.gov.ua, Database of State Statistics Service of Ukraine [06.11.2016]

Бєлова Л.О., 2014, Реформування системи управління освітою за умови децентралізації місцевого самоврядування, Актуальні проблеми державного управління, 1(45), 109-118.

Домбровська С.М., 2010, Державне управління вищою освітою України в умовах трансформачійних змін, Оберіг, Харків.

Закон України від 23 травня 1991 р. "Про освіту", 1991, Вiдомості Верховної Ради України, 1997 №34 Ст. 451.

Інформація абітурієнту Національного університету цивільного захисту України, 2016, http://nuczu.edu.ua/ ukr/for_entrants [06.11.2016].

Інформація абітурієнту Харківського національного автомобільно-дорожнього університету, 2016. http://www.khadi.kharkov.ua/abiturijentu/priiom-douniversitetu/nakazi-na-zarakhuvannja.html [06.11.2016].

Інформачія щодо напрямків підготовки та спеціальностей у Харківському начіональному університеті імені В. Н. Каразіна, 2016, http://www.univer.kharkov.ua/ru/ study/student/bakalavrat [06.11.2016].

Поступна O.B. et al., 2011, Державна політика і управління в освіті, Асоціація докторів наук державного управління, Харків.

Сиченко В.В., 2010, Механізми регулювання системи освіти: сучасний стан та перспективи розвитку, ЮгоВосток, Донецьк. 